\title{
A Study on Hopelessness Levels in Children With and Without Hearing Impairment
}

\author{
Ayhan Babaroglu \\ University of Hitit, Corum, Turkey
}

\begin{abstract}
This study, which was conducted to determine the factors affecting hopelessness levels of children with and without hearing impairment, has been carried out with a total of 161 children ( 81 children with hearing impairment and 80 children without hearing impairment) in the age range of 10-17 years. The Beck Hopelessness Scale and General Information Form were used to collect data. As a result of the study, it has been concluded that age is effective in the hopelessness levels of both children with and without hearing impairment. There are no differences between different sexes in terms of hopelessness. Receiving pre-school education, subscale of feelings about the future, and hearing impairment create a difference on hopelessness levels of children. The hopelessness levels of children who have a member of family with any disability are higher compared to other children. The age of parents has no effect on hopelessness levels. Children with hearing impairment are more hopeless compared to other children. Educational level and employment status of mother create no differences between both groups in terms of hopelessness levels, while educational level and employment status of father affect hopelessness levels of children.
\end{abstract}

Keywords: hearing impairment children, children, hopelessness, hope

\section{Introduction}

In mythology, it has been expressed that all emotions are escaped other than hope when Pandora's Box is opened. Hope is indeed the most reliable basis of life. Hope and hopelessness are two opposite concepts at both ends of the spectrum. Hope can be defined as a feeling for a particular thing to happen or expecting to reach a goal desired. The most important feature of hope is believing that there is a way out and changes may occur with help. Hopelessness can be defined as negative expectations regarding the chance of a particular thing to happen. According to another definition, hopelessness is expressed as a set of negative expectations about the future. In addition, hopelessness reminds the feelings of being trapped, impossibility, and despair. Both hope and hopelessness are the reflections of one's expectations regarding the possibility of reaching future goals. Hope and hopelessness are the symbols of opposite expectations. Hope contains successful future expectations, whereas hopelessness contains failures and mistakes towards future. In hope, there is prediction regarding achievement of the plans to be implemented in the future, while there is prediction of failure in hopelessness. These two opposite expectations may vary from person to person and case to case depending on when and how results expected become true (Minkoff, Bergman, Beck, \& Beck, 1973; Beck, Lesker, \& Trexler, 1974; Bonner \& Rich, 1991; Dilbaz \& Seber, 1993; Gençöz, Vatan, \& Lester, 2006; Vasta, 2015).

Ayhan Bababroğlu, Ph.D., assistant professor, Department of Child Development, Institute of Health Sciences, University of Hitit. 
It is inevitable that children with disabilities, who face physical and functional disabilities, are more sensitive towards problems caused by their situation and its reflections. Hearing impairment is one of the most common types of disabilities in the world. According to the World Health Organization (2011), there were 360,000,000 persons in the world with disabling hearing loss and 32,000,000 of these individuals are children in 2011. Hearing impairment affects individuals in various proportions depending on parents' attitudes and environmental factors as well as degree of hearing impairment. Children need to be able to establish positive relationships to sustain their growth by gaining a healthy self-perception. The negativities experienced by hearing impaired children when entering the socialization process without the chance to choose differ from their peers and these negativities considered as unreachable boundaries despair them; and therefore, aggressive behaviors, such as low self-esteem, despair, worthlessness, and the feelings of anger and frustration, arise in these children.

Difficult and conflictive experiences in early childhood and later in adolescence lead to hopelessness in both individuals with and without any disability and result in important psychological problems, such as depression and suicide. Many researchers suggested that hopelessness is associated with disorders, such as depression and suicidal ideation, and it can be used as an important tool in determining the development risk of these problems (Beck, Kovacs, \& Weissman, 1975; Weissman, 1974; Dyer \& Kreitman, 1984; Turner, Windfuhr, \& Kapur, 2007).

Considering the studies conducted on this subject, it has been determined that hopelessness makes children prone to violence (Bolland, Mccallum, Lian, Bailey, \& Rowan, 2001; Eisenbraun, 2007) and hopelessness scores of boys are higher than those of girls (Küçük \& Arıkan, 2005; Özmen, Erbay Dündar, Çetinkaya, Taşkın, \& Özmen, 2008; Ceylan \& Şahin, 2008; Şahin, 2009; Derman-Taner, 2013). Studies related to hopelessness that can emerge as a result of inabilities and disabilities revealed that children with disabilities experience many problems, such as hopelessness, anxiety/depression, timidity, and attention problems. In these studies, it has been detected that the existence of disability increases the feeling of loneliness and isolation in children and the level of being affected by traumatic events results in hopelessness and depression (Tatar, Çekin, \& Uzun, 1997; Turner et al., 2007; Fellinger, Holzinger, \& Pollard, 2012; Rostami, Bahmani, \& Bakhtyari, 2014; Tanhan \& Kardaş, 2014). In the study of Demir, Bolat, Yavuz, Karaçetin, Doğangün, and Kayaalp (2014) conducted on children and adolescents with disabilities from birth, they have determined that visually impaired group experiences more anxiety/depression, timidity/depression, and attention problems compared to others. Similarly, Koç and Akmeşe Piştav (2011) determined that hopelessness and depression levels of epileptic individuals significantly differ from hopelessness and depression levels of healthy individuals. In the study of Özmen et al. (2008) conducted on high school students, hopelessness levels of students living in rural areas with lower education quality and income were found to be higher.

The prevalence of concepts of hope/hopelessness that have vital importance is noteworthy. Therefore, it is necessary to investigate factors affecting hopelessness of both healthy individuals and individuals with disabilities, because hopelessness affects all components of health. This study aimed to investigate hopelessness levels of both children with and without any impairment and their relationship with factors that may affect hopelessness levels.

\section{Method}

\section{Participants}

For this purpose, 81 children with hearing impairment and 80 children without hearing problems attending a public school between the ages of 10-17 years at similar socio-economic levels in the province of Adana located in the south of Turkey were included in the study (a total of 161 children). While creating population of 
the study, some limitations were introduced as follows: For the group with hearing impairment, participants with no other impairment other than hearing problem at low (25dBHL-40dBHL) ${ }^{1}$ and moderate levels (41dBHL-70dBHL) were selected from families that are still together (not divorced) and capable of evaluating the scales to be implemented; for the other group without hearing impairment, participants without impairment and capable of evaluating the scales to be implemented were selected. Demographic information of the students included in the study are presented in Table 1.

Table 1

Demographic Information About the Sample

\begin{tabular}{|c|c|c|c|c|c|}
\hline \multirow{2}{*}{ Variables } & & \multicolumn{2}{|c|}{ Children with hearing impairment } & \multicolumn{2}{|c|}{ Children without hearing impairment } \\
\hline & & $N$ & $\%$ & $N$ & $\%$ \\
\hline \multirow{2}{*}{ Gender } & Female & 32 & 39.51 & 45 & 56.25 \\
\hline & Male & 49 & 60.49 & 35 & 43.75 \\
\hline \multirow{8}{*}{ Age } & 10 & 8 & 9.87 & 8 & 10 \\
\hline & 11 & 7 & 8.64 & 10 & 12.5 \\
\hline & 12 & 12 & 14.81 & 10 & 12.5 \\
\hline & 13 & 8 & 9.87 & 7 & 8.75 \\
\hline & 14 & 14 & 17.28 & 11 & 13.75 \\
\hline & 15 & 13 & 16.05 & 12 & 15 \\
\hline & 16 & 12 & 14.81 & 10 & 12.5 \\
\hline & 17 & 7 & 8.64 & 12 & 13.75 \\
\hline \multirow{2}{*}{$\begin{array}{l}\text { Pre-school education } \\
\text { receiving status }\end{array}$} & I receive & 52 & 64.20 & 28 & 35 \\
\hline & I did not receive & 29 & 35.80 & 52 & 65 \\
\hline \multirow{4}{*}{ Mother's age } & $18-25$ & 2 & 2.47 & - & - \\
\hline & $26-36$ & 34 & 41.97 & 11 & 13.75 \\
\hline & $37-49$ & 43 & 53.09 & 62 & 77.5 \\
\hline & $50+$ & 2 & 2.47 & 7 & 8.75 \\
\hline \multirow{4}{*}{$\begin{array}{l}\text { Mother's } \\
\text { educational level }\end{array}$} & Illiterate & 20 & 24.69 & 7 & 8.75 \\
\hline & Primary school & 61 & 75.31 & 55 & 68.75 \\
\hline & High school and equivalent & - & - & 12 & 15 \\
\hline & University & - & - & 6 & 7.5 \\
\hline \multirow{2}{*}{$\begin{array}{l}\text { Mother's } \\
\text { employment status }\end{array}$} & Working & 7 & 7.41 & 18 & 22.5 \\
\hline & Not working & 75 & 92.59 & 62 & 77.5 \\
\hline \multirow{4}{*}{ Father's age } & $18-25$ & - & - & - & - \\
\hline & $26-36$ & 10 & 12.35 & 1 & 1.25 \\
\hline & $37-49$ & 56 & 69.13 & 57 & 71.25 \\
\hline & $\geq 50$ & 15 & 18.52 & 22 & 27.5 \\
\hline \multirow{4}{*}{$\begin{array}{l}\text { Father's educational } \\
\text { level }\end{array}$} & Illiterate & 9 & 11.11 & 2 & 2.5 \\
\hline & Primary school & 67 & 82.72 & 44 & 55 \\
\hline & High school and equivalent & 5 & 6.17 & 25 & 31.25 \\
\hline & University & - & - & 9 & 11.25 \\
\hline \multirow{2}{*}{$\begin{array}{l}\text { Father's } \\
\text { employment status }\end{array}$} & Working & 62 & 76.54 & 71 & 88.75 \\
\hline & Not working & 19 & 23.46 & 9 & 11.25 \\
\hline \multirow{4}{*}{$\begin{array}{l}\text { The case of other } \\
\text { individual with } \\
\text { impaired in the } \\
\text { family }\end{array}$} & No & 38 & 46.91 & 74 & 92.5 \\
\hline & One or more siblings & 31 & 38.27 & 5 & 6.25 \\
\hline & Mother and father & 4 & 4.94 & 1 & 1.25 \\
\hline & Whole family & 8 & 9.88 & - & - \\
\hline
\end{tabular}

1 dBHL: dB_-decibel (refers to the power of sound); HL-hearing level. According to British grading system, hearing loss can be seen in varying degrees: 25-40 dBHL_Low, 41-70 dBHL-Moderate, 71-95 dBHL-Advanced, and 96 \pm dBHL-Too advanced. 


\section{Procedure}

After determining the schools to be surveyed, required permissions are obtained. Then, these schools were contacted and teachers and students were informed about the study. This study was conducted based on volunteering. Demographic information of the students included in the study was presented in the General Information Form. Then, the Beck Hopelessness Scale was explained to the children with hearing impairment by using the method of communication they prefer to use (verbal method, sign language, and total method). Each student filled out the form in an empty room. There was no time limitation set for students while filling out the form. Required disclosures were made when needed. A similar procedure was applied on other children without hearing impairment.

As a result of the normality test (Kolmogorov-Smirnov) applied on the data obtained in order to determine the effects of variables set for children in the sample group on their hopelessness levels, data distribution was found to be normal and Duncan test was employed to find the significance of differences between characters, in which variance ( $F$-test) was applied. Statistical analyses were performed using the Statistical Package for Social Sciences (SPSS) software package.

\section{Data Collection Tool}

The Beck Hopelessness Scale and General Information Form were used to collect some demographic data of the group included in the study.

The Beck Hopelessness Scale, which was developed by Beck et al. (1974) in order to determine the degree of pessimism of an individual for the future, is a 20-item self-report inventory with high reliability and validity. Each question has two answers as "Yes" and "No" and each correct answer gets 1 point while wrong answers receive no points. The total score received is accepted as "hopelessness" score. The lowest score that can be received from the scale is 0 , whereas the highest score is 20 . Scores of 0-6 are considered as low, 7-13 are considered as moderate, and 14-20 are as high scores, respectively. Questions forming the scale covers emotional, motivational, and cognitive dimensions. The scale is composed of three factors: "feelings about the future," "loss of motivation," and "expectations about the future" (Beck et al., 1974).

Translation of the Beck Hopelessness Scale into Turkish and its validity and reliability studies were done by Seber (1991). Then, Durak (1994) obtained more detailed information about validity, reliability, and factor structure of the scale.

\section{Results}

Considering the data given in Table 2, it has been seen that hopelessness levels of children vary depending on age of the children $(F=2.592 ; p=0.015)$, and hopelessness levels of children with and without hearing impairment differ from each other regardless of age only when they are 15 years old. Hopelessness levels of 15 years old children with hearing impairment were found to be higher than hopelessness levels of 15 years old children without hearing impairment. In the subscale of feeling about the future, hearing impairment is found to be effective on hopelessness $(F=7.664 ; p=0.006)$. In this subscale, hopelessness levels of children with hearing impairment were found to be higher than hopelessness levels of children without hearing impairment. In the subscales of loss of motivation and expectations about the future, no differences were found between the two groups.

Considering the data presented in Table 3, it has been seen that age does not affect hopelessness levels $(F=0.031 ; p=0.861)$. However, hearing impairment creates a difference in the subscale of feeling about the 
future $(F=6.441 ; p=0.012)$ and hopelessness levels of children with hearing impairment are found to be higher than hopelessness levels of children without hearing impairment in the subscale of feelings about the future regardless of sex of the children.

Table 2

Hopelessness Scores and Age

\begin{tabular}{|c|c|c|c|c|c|c|c|c|}
\hline \multirow[b]{2}{*}{ Age } & \multicolumn{2}{|c|}{ Hopelessness ${ }^{1}$} & \multicolumn{2}{|c|}{ Feelings for the future } & \multicolumn{2}{|c|}{ Motivation loss } & \multicolumn{2}{|c|}{ Expectations for the future } \\
\hline & $\begin{array}{l}\text { Hearing } \\
\text { impaired }\end{array}$ & Hearing & $\begin{array}{l}\text { Hearing } \\
\text { impaired }\end{array}$ & Hearing & $\begin{array}{l}\text { Hearing } \\
\text { impaired }\end{array}$ & Hearing & $\begin{array}{l}\text { Hearing } \\
\text { impaired }\end{array}$ & Hearing \\
\hline 10 & $14.62 \pm 1.22$ & $14.00 \pm 1.45$ & $5.12 \pm 0.40$ & $4.50 \pm 0.38$ & $6.25 \pm 0.77$ & $6.00 \pm 0.84$ & $3.25 \pm 0.41$ & $3.62 \pm 0.42$ \\
\hline 11 & $16.57 \pm 0.99$ & $13.80 \pm 1.45$ & $5.28 \pm 0.28$ & $4.40 \pm 0.37$ & $7.00 \pm 0.72$ & $5.60 \pm 0.88$ & $4.28 \pm 0.36$ & $3.90 \pm 0.41$ \\
\hline 12 & $13.75 \pm 1.19$ & $16.80 \pm 0.81$ & $4.83 \pm 0.36$ & $5.40 \pm 0.22$ & $5.83 \pm 0.78$ & $7.40 \pm 0.60$ & $3.08 \pm 0.29$ & $4.00 \pm 0.29$ \\
\hline 13 & $16.37 \pm 1.58$ & $15.00 \pm 1.36$ & $5.12 \pm 0.44$ & $4.71 \pm 0.28$ & $7.37 \pm 0.73$ & $7.28 \pm 0.94$ & $3.87 \pm 0.83$ & $3.71 \pm 0.64$ \\
\hline 14 & $13.07 \pm 1.48$ & $16.54 \pm 0.65$ & $4.62 \pm 0.49$ & $4.73 \pm 0.14$ & $5.28 \pm 0.77$ & $7.73 \pm 0.43$ & $3.14 \pm 0.42$ & $4.18 \pm 0.26$ \\
\hline 15 & $17.61 \pm 0.82 \mathrm{~A}^{3}$ & $14.17 \pm 1.29 \mathrm{~B}$ & $5.61 \pm 0.43$ & $4.25 \pm 0.43$ & $8.08 \pm 0.35$ & $6.00 \pm 0.61$ & $3.92 \pm 0.21$ & $4.00 \pm 0.44$ \\
\hline 16 & $15.58 \pm 1.00$ & $16.60 \pm 0.89$ & $5.33 \pm 0.26$ & $4.80 \pm 0.20$ & $7.08 \pm 0.64$ & $7.90 \pm 0.67$ & $3.25 \pm 0.25$ & $3.90 \pm 0.31$ \\
\hline 17 & $15.14 \pm 1.53$ & $13.17 \pm 0.99$ & $5.14 \pm 0.40$ & $4.08 \pm 0.31$ & $6.71 \pm 0.99$ & $5.25 \pm 0.54$ & $3.43 \pm 0.29$ & $3.83 \pm 0.42$ \\
\hline Mean & - & - & $5.12 \pm 1.31 \mathrm{~A}^{3}$ & $4.59 \pm 0.11 \mathrm{~B}$ & - & - & - & - \\
\hline $\begin{array}{l}\text { Hearing } \\
\mathrm{X} \text { age }\end{array}$ & \multicolumn{2}{|c|}{$F=2.592 ; p=0.015$} & \multicolumn{2}{|c|}{$F=1.547 ; p=0.156$} & \multicolumn{2}{|c|}{$F=2.845 ; p=0.08$} & \multicolumn{2}{|c|}{$F=0.908 ; p=0.502$} \\
\hline Age & \multicolumn{2}{|c|}{$F=0.679 ; p=0.689$} & \multicolumn{2}{|c|}{$F=0.448 ; p=0.870$} & \multicolumn{2}{|c|}{$F=1.173 ; p=0.322$} & \multicolumn{2}{|c|}{$F=0.678 ; p=0.691$} \\
\hline Hearing & \multicolumn{2}{|c|}{$F=0.292 ; p=0.590$} & \multicolumn{2}{|c|}{$F=7.664 ; p=0.006$} & \multicolumn{2}{|c|}{$F=0.025 ; p=0.874$} & \multicolumn{2}{|c|}{$F=3.72 ; p=0.066$} \\
\hline
\end{tabular}

Notes. ${ }^{1}$ Each size is assessed in itself;

${ }^{2}$ Different small letters in the same column are different from the statistical point of view;

${ }^{3}$ Big letters different in the same row are different from the statistical point of view.

Table 3

Hopelessness Scores and Gender

\begin{tabular}{|c|c|c|c|c|c|c|c|c|}
\hline \multirow[b]{2}{*}{ Gender } & \multicolumn{2}{|c|}{ Hopelessness $^{1}$} & \multicolumn{2}{|c|}{ Feelings for the future } & \multicolumn{2}{|c|}{ Motivation loss } & \multicolumn{2}{|c|}{ Expectations for the future } \\
\hline & $\begin{array}{l}\text { Hearing } \\
\text { impaired }\end{array}$ & Hearing & $\begin{array}{l}\text { Hearing } \\
\text { impaired }\end{array}$ & Hearing & $\begin{array}{l}\text { Hearing } \\
\text { impaired }\end{array}$ & Hearing & $\begin{array}{l}\text { Hearing } \\
\text { impaired }\end{array}$ & Hearing \\
\hline Female & $14.72 \pm 0.69$ & $14.71 \pm 0.59$ & $4.81 \pm 0.21$ & $4.55 \pm 0.17$ & $6.59 \pm 0.41$ & $6.44 \pm 0.35$ & $3.34 \pm 0.20$ & $3.89 \pm 0.19$ \\
\hline Male & $15.75 \pm 0.56$ & $15.34 \pm 0.66$ & $5.33 \pm 0.17$ & $4.63 \pm 0.19$ & $6.69 \pm 0.33$ & $6.80 \pm 0.39$ & $3.57 \pm 0.15$ & $3.94 \pm 0.19$ \\
\hline Mean & - & - & $5.12 \pm 0.13 \mathrm{~A}^{3}$ & $4.59 \pm 0.13 \mathrm{~B}$ & - & - & $3.48 \pm 0.12 \mathrm{~B}$ & $3.91 \pm 0.14 \mathrm{~A}$ \\
\hline $\begin{array}{l}\text { Hearing } \\
\mathrm{X} \text { gender }\end{array}$ & \multicolumn{2}{|c|}{$F=0.031 ; p=0.861$} & \multicolumn{2}{|c|}{$F=1.374 ; p=0.243$} & \multicolumn{2}{|c|}{$F=0.11 ; p=0.734$} & \multicolumn{2}{|c|}{$F=0.219 ; p=0.641$} \\
\hline Gender & \multicolumn{2}{|c|}{$F=1.379 ; p=0.239$} & \multicolumn{2}{|c|}{$F=2.434 ; p=0.121$} & \multicolumn{2}{|c|}{$F=0.369 ; p=0.545$} & \multicolumn{2}{|c|}{$F=0.575 ; p=0.450$} \\
\hline Hearing & \multicolumn{2}{|c|}{$F=0.035 ; p=0.851$} & \multicolumn{2}{|c|}{$F=6.441 ; p=0.012$} & \multicolumn{2}{|c|}{$F=0.003 ; p=0.954$} & \multicolumn{2}{|c|}{$F=6.086 ; p=0.015$} \\
\hline
\end{tabular}

Notes. ${ }^{1}$ Each size is assessed in itself;

${ }^{2}$ Different small letters in the same column are different from the statistical point of view;

${ }^{3}$ Big letters different in the same row are different from the statistical point of view.

In addition, although it is not statistically significant, hopelessness levels of boys with hearing impairment are found to be higher than hopelessness levels of girls in the subscale of feelings about the future. In the subscale of expectations about the future, hopelessness levels of children without hearing impairment are found to be higher than hopelessness levels of children with hearing impairment. No differences were found in the subscale of loss of motivation. 
According to Table 4, receiving pre-school education has no impact on hopelessness levels of children $(F=0.043 ; p=0.836)$. However, in the subscale of feelings about the future, it is noteworthy that although receiving pre-school education does not create any difference, hearing impairment creates a difference between groups. In this subscale, hopelessness levels of children with hearing impairment are higher than hopelessness levels of children without hearing impairment. In the subscales of loss of motivation and expectations about the future, no differences were found between the two groups.

Table 4

Hopelessness Scores and Pre-school Education Receiving Status

\begin{tabular}{|c|c|c|c|c|c|c|c|c|}
\hline \multirow{2}{*}{$\begin{array}{l}\text { Pre-school } \\
\text { education } \\
\text { Receiving } \\
\text { status }\end{array}$} & \multicolumn{2}{|c|}{ Hopelessness $^{1}$} & \multicolumn{2}{|c|}{ Feelings for the future } & \multicolumn{2}{|c|}{ Motivation loss } & \multicolumn{2}{|c|}{ Expectations for the future } \\
\hline & $\begin{array}{l}\text { Hearing } \\
\text { impaired }\end{array}$ & Hearing & $\begin{array}{l}\text { Hearing } \\
\text { impaired }\end{array}$ & Hearing & $\begin{array}{l}\text { Hearing } \\
\text { impaired }\end{array}$ & Hearing & $\begin{array}{l}\text { Hearing } \\
\text { impaired }\end{array}$ & Hearing \\
\hline I did not receive & $15.17 \pm 0.58$ & $14.75 \pm 0.73$ & $5.10 \pm 0.20$ & $4.69 \pm 0.21$ & $6.52 \pm 0.39$ & $6.28 \pm 0.40$ & $3.55 \pm 0.17$ & $3.82 \pm 0.22$ \\
\hline I receive & $15.27 \pm 0.64$ & $15.11 \pm 0.50$ & $5.13 \pm 0.20$ & $4.54 \pm 0.14$ & $6.73 \pm 0.35$ & $6.77 \pm 0.32$ & $3.44 \pm 0.16$ & $3.96 \pm 0.17$ \\
\hline Mean & - & - & $5.12 \pm 0.15 \mathrm{~A}^{3}$ & $4.59 \pm 0.11 \mathrm{~B}$ & & - & - & - \\
\hline $\begin{array}{l}\text { Hearing X } \\
\text { education }\end{array}$ & \multicolumn{2}{|c|}{$F=0.043 ; p=0.836$} & \multicolumn{2}{|c|}{$F=0.191 ; p=0.663$} & \multicolumn{2}{|c|}{$F=0.122 ; p=0.727$} & \multicolumn{2}{|c|}{$F=0.424 ; p=0.516$} \\
\hline Education & \multicolumn{2}{|c|}{$F=0.127 ; p=0.722$} & \multicolumn{2}{|c|}{$F=0.077 ; p=0.781$} & \multicolumn{2}{|c|}{$F=0.816 ; p=0.36$} & \multicolumn{2}{|c|}{$F=0.006 ; p=0.936$} \\
\hline Hearing & \multicolumn{2}{|c|}{$F=0.197 ; p=0.658$} & \multicolumn{2}{|c|}{$F=6.792 ; p=0.010$} & \multicolumn{2}{|c|}{$F=0.063 ; p=0.803$} & \multicolumn{2}{|c|}{$F=4.242 ; p=0.041$} \\
\hline
\end{tabular}

Notes. ${ }^{1}$ Each size is assessed in itself;

${ }^{2}$ Different small letters in the same column are different from the statistical point of view;

${ }^{3}$ Big letters different in the same row are different from the statistical point of view.

As it can be seen in Table 5, the existence of another disabled family member creates no statistically important differences between groups in terms of hopelessness levels $(F=0.419 ; p=0.518)$. However, it is worthy of note that hopelessness levels of children with hearing impairment stating that there are family members with hearing impairment or other disabilities in the entire family are high. No differences were found in other subscales.

Table 5

Hopelessness Scores and Existence of Other Individual Impaired in the Family

\begin{tabular}{|c|c|c|c|c|c|c|c|c|}
\hline \multirow{2}{*}{$\begin{array}{l}\text { Existence of } \\
\text { other individual } \\
\text { impaired in the } \\
\text { family }\end{array}$} & \multicolumn{2}{|c|}{ Hopelessness $^{1}$} & \multicolumn{2}{|c|}{ Feelings for the future } & \multicolumn{2}{|c|}{ Motivation loss } & \multicolumn{2}{|c|}{ Expectations for the future } \\
\hline & $\begin{array}{l}\text { Hearing } \\
\text { impaired }\end{array}$ & Hearing & $\begin{array}{l}\text { Hearing } \\
\text { impaired }\end{array}$ & Hearing & $\begin{array}{l}\text { Hearing } \\
\text { impaired }\end{array}$ & Hearing & $\begin{array}{l}\text { Hearing } \\
\text { impaired }\end{array}$ & Hearing \\
\hline No & $15.29 \pm 0.64$ & $14.93 \pm 0.46$ & $5.21 \pm 0.19$ & $4.58 \pm 014$ & $6.74 \pm 0.38$ & $6.58 \pm 0.27$ & $3.37 \pm 0.19$ & $3.89 \pm 0.14$ \\
\hline $\begin{array}{l}\text { One or more } \\
\text { siblings }\end{array}$ & $14.77 \pm 0.71$ & $15.67 \pm 1.61$ & $4.97 \pm 0.21$ & $4.67 \pm 0.49$ & $6.22 \pm 0.42$ & $6.83 \pm 0.96$ & $3.61 \pm 0.21$ & $4.17 \pm 0.48$ \\
\hline $\begin{array}{l}\text { Mother and } \\
\text { father }\end{array}$ & $16.00 \pm 1.97$ & - & $5.00 \pm 0.59$ & - & $7.75 \pm 117$ & - & $3.25 \pm 0.58$ & - \\
\hline Whole family & $16.37 \pm 1.39$ & - & $5.37 \pm 0.42$ & - & $7.37 \pm 0.83$ & - & $3.62 \pm 0.41$ & - \\
\hline $\begin{array}{l}\text { Hearing X other } \\
\text { impaired }\end{array}$ & \multicolumn{2}{|c|}{$F=0.419 ; p=0.518$} & \multicolumn{2}{|c|}{$F=0.317 ; p=0.574$} & \multicolumn{2}{|c|}{$F=0.445 ; p=0.506$} & \multicolumn{2}{|c|}{$F=0.003 ; p=0.775$} \\
\hline Other impaired & \multicolumn{2}{|c|}{$F=0.338 ; p=0.798$} & \multicolumn{2}{|c|}{$F=0.173 ; p=0.915$} & \multicolumn{2}{|c|}{$F=0.680 ; p=0.566$} & \multicolumn{2}{|c|}{$F=0.369 ; p=0.775$} \\
\hline Hearing & \multicolumn{2}{|c|}{$F=0.077 ; p=0.782$} & \multicolumn{2}{|c|}{$F=2.549 ; p=0.112$} & \multicolumn{2}{|c|}{$F=0.156 ; p=0.694$} & \multicolumn{2}{|c|}{$F=3.574 ; p=0.061$} \\
\hline
\end{tabular}

Notes. ${ }^{1}$ Each size is assessed in itself;

${ }^{2}$ Different small letters in the same column are different from the statistical point of view;

${ }^{3}$ Big letters different in the same row are different from the statistical point of view. 
In Table 6, data regarding the age of mother are presented. According to the data presented in the table, age of mother has no impact on hopelessness levels of children $(F=1.737 ; p=0.179)$; however, hopelessness levels of children with hearing impairment, whose mothers are aged 50 and above, are found to be high. In the subscale of feeling about the future, hearing impairment is found to be effective $(F=7.403 ; p=0.007)$. In this subscale, hopelessness levels of children with hearing impairment are higher than hopelessness levels of children without hearing impairment. There were no differences in other subscales.

Table 6

Hopelessness Scores and Mother's Age

\begin{tabular}{|c|c|c|c|c|c|c|c|c|}
\hline \multirow[b]{2}{*}{ Mother's age } & \multicolumn{2}{|c|}{ Hopelessness $^{1}$} & \multicolumn{2}{|c|}{ Feelings for the future } & \multicolumn{2}{|c|}{ Motivation loss } & \multicolumn{2}{|c|}{ Expectations for the future } \\
\hline & $\begin{array}{l}\text { Hearing } \\
\text { impaired }\end{array}$ & Hearing & $\begin{array}{l}\text { Hearing } \\
\text { impaired }\end{array}$ & Hearing & $\begin{array}{l}\text { Hearing } \\
\text { impaired }\end{array}$ & Hearing & $\begin{array}{l}\text { Hearing } \\
\text { impaired }\end{array}$ & Hearing \\
\hline $18-25$ & $17.50 \pm 2.77$ & - & $5.50 \pm 0.83$ & - & $8.50 \pm 1.63$ & - & $3.50 \pm 0.83$ & - \\
\hline $26-36$ & $15.44 \pm 0.67$ & $16.18 \pm 1.18$ & $5.09 \pm 0.20$ & $4.82 \pm 0.35$ & $6.91 \pm 0.39$ & $7.45 \pm 0.69$ & $3.44 \pm 0.22$ & $3.91 \pm 0.35$ \\
\hline $37-47$ & $14.79 \pm 0.59$ & $14.94 \pm 0.49$ & $5.07 \pm 0.18$ & $4.57 \pm 0.15$ & $6.28 \pm 0.35$ & $6.59 \pm 0.29$ & $3.49 \pm 0.17$ & $3.92 \pm 0.14$ \\
\hline$\geq 50$ & $19.00 \pm 1.00$ & $13.33 \pm 1.59$ & $6.50 \pm 0.83$ & $4.33 \pm 0.48$ & $8.50 \pm 1.63$ & $5.17 \pm 0.94$ & $4.00 \pm 0.83$ & $3.83 \pm 0.47$ \\
\hline Mean & - & - & $5.12 \pm 0.30 \mathrm{~A}^{2}$ & $4.59 \pm 0.21 \mathrm{~B}$ & - & - & - & - \\
\hline $\begin{array}{l}\text { Hearing X } \\
\text { Mother's age }\end{array}$ & \multicolumn{2}{|c|}{$F=1.737 ; p=0.179$} & \multicolumn{2}{|c|}{$F=1.632 ; p=0.199$} & \multicolumn{2}{|c|}{$F=1.871 ; p=0.158$} & \multicolumn{2}{|c|}{$F=0.196 ; p=0.823$} \\
\hline Mother's age & \multicolumn{2}{|c|}{$F=0.740 ; p=0.530$} & \multicolumn{2}{|c|}{$F=0.556 ; p=0.645$} & \multicolumn{2}{|c|}{$F=1.125 ; p=0.341$} & \multicolumn{2}{|c|}{$F=0.073 ; p=0.974$} \\
\hline Hearing & \multicolumn{2}{|c|}{$F=1.806 ; p=0.181$} & \multicolumn{2}{|c|}{$F=7.403 ; p=0.007$} & \multicolumn{2}{|c|}{$F=1.395 ; p=0.239$} & \multicolumn{2}{|c|}{$F=0.473 ; p=0.493$} \\
\hline
\end{tabular}

Notes. ${ }^{1}$ Each size is assessed in itself;

${ }^{2}$ Different small letters in the same column are different from the statistical point of view;

${ }^{3}$ Big letters different in the same row are different from the statistical point of view.

According to the data given in Table 7, age of father has no impact on hopelessness levels of children $(F=1.630 ; p=0.204)$. In the subscale of feelings about the future, the existence of hearing impairment affects hopelessness levels of children regardless of age and increases hopelessness levels of children with hearing impairment. No differences were found in other subscales.

Table 7

Hopelessness Scores and Father's Age

\begin{tabular}{|c|c|c|c|c|c|c|c|c|}
\hline \multirow[b]{2}{*}{ Father's age } & \multicolumn{2}{|c|}{ Hopelessness $^{1}$} & \multicolumn{2}{|c|}{ Feelings for the future } & \multicolumn{2}{|c|}{ Motivation loss } & \multicolumn{2}{|c|}{ Expectations for the future } \\
\hline & $\begin{array}{l}\text { Hearing } \\
\text { impaired }\end{array}$ & Hearing & $\begin{array}{l}\text { Hearing } \\
\text { impaired }\end{array}$ & Hearing & $\begin{array}{l}\text { Hearing } \\
\text { impaired }\end{array}$ & Hearing & $\begin{array}{l}\text { Hearing } \\
\text { impaired }\end{array}$ & Hearing \\
\hline $26-36$ & $16.30 \pm 1.24$ & - & $5.10 \pm 0.37$ & - & $7.70 \pm 0.73$ & - & $3.50 \pm 0.36$ & - \\
\hline $37-47$ & $14.77 \pm 0.52$ & $15.10 \pm 0.51$ & $5.03 \pm 0.15$ & $4.69 \pm 0.15$ & $6.37 \pm 0.31$ & $6.71 \pm 0.30$ & $3.39 \pm 0.15$ & $3.83 \pm 0.15$ \\
\hline$\geq 50$ & $16.26 \pm 1.01$ & $14.68 \pm 0.84$ & $5.47 \pm 0.30$ & $4.31 \pm 0.25$ & $7.00 \pm 0.60$ & $6.32 \pm 0.49$ & $3.80 \pm 0.29$ & $4.14 \pm 024$ \\
\hline Mean & - & - & $5.12 \pm 0.16 \mathrm{~A}^{-}$ & $4.58 \pm 0.14 \mathrm{~B}$ & - & - & - & - \\
\hline $\begin{array}{l}\text { Hearing X } \\
\text { father's age }\end{array}$ & \multicolumn{2}{|c|}{$F=1.630 ; p=0.204$} & \multicolumn{2}{|c|}{$F=3.133 ; p=0.079$} & \multicolumn{2}{|c|}{$F=1.287 ; p=0.258$} & \multicolumn{2}{|c|}{$F=0.049 ; p=0.825$} \\
\hline Father's age & \multicolumn{2}{|c|}{$F=0.513 ; p=0.600$} & \multicolumn{2}{|c|}{$F=0.070 ; p=0.933$} & \multicolumn{2}{|c|}{$F=0.906 ; p=0.206$} & \multicolumn{2}{|c|}{$F=1.300 ; p=0.275$} \\
\hline Hearing & \multicolumn{2}{|c|}{$F=0.690 ; p=0.407$} & \multicolumn{2}{|c|}{$F=10.870 ; p=0.001$} & \multicolumn{2}{|c|}{$F=0.153 ; p=0.696$} & \multicolumn{2}{|c|}{$F=3.013 ; p=0.085$} \\
\hline
\end{tabular}

Notes. ${ }^{1}$ Each size is assessed in itself;

${ }^{2}$ Different small letters in the same column are different from the statistical point of view;

${ }^{3}$ Big letters different in the same row are different from the statistical point of view. 
According to Table 8, the employment status of mother has no effect on hopelessness levels of children $(F=0.009 ; p=0.991)$. In the subscales of feelings about the future, loss of motivation, and expectations about the future, it is still same. However, in the group of children with hearing impairment, the presence of illiterate mothers and mothers with primary education is noteworthy.

Table 8

Hopelessness Scores and Mother's Educational Level

\begin{tabular}{|c|c|c|c|c|c|c|c|c|}
\hline \multirow{2}{*}{$\begin{array}{l}\text { Mother's } \\
\text { educational } \\
\text { level }\end{array}$} & \multicolumn{2}{|c|}{ Hopelessness $^{1}$} & \multicolumn{2}{|c|}{ Feelings for the future } & \multicolumn{2}{|c|}{ Motivation loss } & \multicolumn{2}{|c|}{ Expectations for the future } \\
\hline & $\begin{array}{l}\text { Hearing } \\
\text { impaired }\end{array}$ & Hearing & $\begin{array}{l}\text { Hearing } \\
\text { impaired }\end{array}$ & Hearing & $\begin{array}{l}\text { Hearing } \\
\text { impaired }\end{array}$ & Hearing & $\begin{array}{l}\text { Hearing } \\
\text { impaired }\end{array}$ & Hearing \\
\hline Illiterate & $15.05 \pm 0.88$ & $14.57 \pm 1.49$ & $4.80 \pm 0.26$ & $4.43 \pm 0.44$ & $6.75 \pm 0.52$ & $6.43 \pm 0.89$ & $3.55 \pm 0.25$ & $3.71 \pm 0.25$ \\
\hline $\begin{array}{l}\text { Primary } \\
\text { school }\end{array}$ & $15.29 \pm 0.50$ & $14.82 \pm 0.53$ & $5.23 \pm 0.15$ & $4.56 \pm 0.16$ & $6.62 \pm 0.30$ & $6.58 \pm 0.31$ & $3.46 \pm 0.14$ & $3.80 \pm 0.15$ \\
\hline $\begin{array}{l}\text { High school } \\
\text { and equivalent }\end{array}$ & - & $15.92 \pm 1.14$ & - & $4.75 \pm 0.34$ & - & $6.83 \pm 0.68$ & - & $4.50 \pm 0.33$ \\
\hline University & - & $15.17 \pm 1.61$ & - & $4.67 \pm 0.48$ & - & $6.50 \pm 0.96$ & - & $4.00 \pm 0.47$ \\
\hline $\begin{array}{l}\text { Hearing X } \\
\text { mother's } \\
\text { education }\end{array}$ & \multicolumn{2}{|c|}{$F=0.009 ; p=0.991$} & \multicolumn{2}{|c|}{$F=0.270 ; p=0.604$} & \multicolumn{2}{|c|}{$F=0.062 ; p=0.804$} & \multicolumn{2}{|c|}{$F=0.103 ; p=0.749$} \\
\hline $\begin{array}{l}\text { Mother's } \\
\text { education }\end{array}$ & \multicolumn{2}{|c|}{$F=0.260 ; p=0.854$} & \multicolumn{2}{|c|}{$F=0.353 ; p=0.787$} & \multicolumn{2}{|c|}{$F=0.060 ; p=0.981$} & \multicolumn{2}{|c|}{$F=1.305 ; p=0.275$} \\
\hline Hearing & \multicolumn{2}{|c|}{$F=0.257 ; p=0.613$} & \multicolumn{2}{|c|}{$F=3.351 ; p=0.069$} & \multicolumn{2}{|c|}{$F=0.104 ; p=0.748$} & \multicolumn{2}{|c|}{$F=0.839 ; p=0.361$} \\
\hline
\end{tabular}

Notes. ${ }^{1}$ Each size is assessed in itself;

${ }^{2}$ Different small letters in the same column are different from the statistical point of view;

${ }^{3}$ Big letters different in the same row are different from the statistical point of view.

Considering the data given in Table 9, it has been seen that educational level of father has an impact on children's hopelessness levels $(F=4.758 ; p=0.010)$. Hopelessness levels of children with hearing impairment, whose fathers are illiterate or holding a high school degree, are found to be higher compared to other children. In addition, while hopelessness levels of children with hearing impairment, whose fathers are illiterate or holding a high school degree, are higher, hopelessness levels of children without hearing impairment, whose fathers are graduated from universities, are found to be higher, respectively. In the subscale of feelings about the future, hopelessness levels of children with hearing impairment, whose fathers are illiterate, are found to be higher that hopelessness levels of children without hearing problems. In this subscale, it is noteworthy that hopelessness levels of children with illiterate fathers are lower than hopelessness levels of children without hearing impairment. In the subscale of loss of motivation, hopelessness levels of children with hearing impairment, whose fathers are illiterate or holding a high school degree, are higher than hopelessness levels of children without hearing impairment. In the group of children without hearing impairment, while hopelessness levels of children whose fathers are graduated from universities are found to be the highest, hopelessness levels of children whose fathers are illiterate are found to be at lowest values. No differences were found in the subscale of expectations about the future.

As it can be seen in Table 10, employment status of mother has no impact on hopelessness levels of children $(F=1.219 ; p=0.271)$. In addition, in the group of children with hearing impairment, although it is not statistically significant, hopelessness levels of children whose mothers have a job are found to be higher; whereas in the group of children without hearing impairment, hopelessness levels of children whose mothers do not have a job are found to be higher, respectively. In the subscale of feelings about the future, hearing impairment 
creates a difference regardless of employments status of mother $(F=3.872 ; p=0.050)$. In the subscale of feelings about the future, hopelessness levels of children with hearing impairment are found to be higher than hopelessness levels of children without hearing impairment. No differences were found in other subscales.

Table 9

Hopelessness Scores and Father's Educational Level

\begin{tabular}{|c|c|c|c|c|c|c|c|c|}
\hline \multirow{2}{*}{$\begin{array}{l}\text { Father's } \\
\text { educational level }\end{array}$} & \multicolumn{2}{|c|}{ Hopelessness 1} & \multicolumn{2}{|c|}{ Feelings for the future } & \multicolumn{2}{|c|}{ Motivation loss } & \multicolumn{2}{|c|}{ Expectations for the future } \\
\hline & $\begin{array}{l}\text { Hearing } \\
\text { impaired }\end{array}$ & Hearing & $\begin{array}{l}\text { Hearing } \\
\text { impaired }\end{array}$ & Hearing & $\begin{array}{l}\text { Hearing } \\
\text { impaired }\end{array}$ & Hearing & $\begin{array}{l}\text { Hearing } \\
\text { impaired }\end{array}$ & Hearing \\
\hline Illiterate & $\begin{array}{l}15.33 \pm 1.26 \\
b^{2} \mathrm{~A}^{3}\end{array}$ & $10.00 \pm 2.72 \mathrm{bB}$ & $5.22 \pm 0.41 \mathrm{~A}$ & $3.00 \pm 0.82 \mathrm{bB}$ & $6.78 \pm 0.74 \mathrm{bA}$ & $3.50 \pm 1.62 \mathrm{bB}$ & $3.44 \pm 0.36$ & $3.50 \pm 0.81$ \\
\hline Primary school & $14.97 \pm 0.47 \mathrm{~b}$ & $15.59 \pm 0.58 \mathrm{a}$ & $5.06 \pm 0.14$ & $4.79 \pm 0.17 \mathrm{a}$ & $6.51 \pm 0.28 b$ & $7.00 \pm 0.34 \mathrm{a}$ & $3.42 \pm 0.14$ & $3.95 \pm 0.17$ \\
\hline $\begin{array}{l}\text { High school and } \\
\text { equivalent }\end{array}$ & $18.60 \pm 1.72 \mathrm{aA}$ & $14.00 \pm 0.77 \mathrm{aB}$ & $5.80 \pm 0.52$ & $4.32 \pm 0.23 \mathrm{a}$ & $8.40 \pm 1.03 \mathrm{aA}$ & $6.00 \pm 0.45 \mathrm{aB}$ & $4.40 \pm 0.51$ & $3.72 \pm 0.23$ \\
\hline University & - & $15.89 \pm 1.28 \mathrm{a}$ & - & $4.67 \pm 0.39 \mathrm{a}$ & - & $7.00 \pm 0.76 \mathrm{a}$ & - & $4.33 \pm 0.38$ \\
\hline $\begin{array}{l}\text { Hearing X } \\
\text { father's } \\
\text { education }\end{array}$ & \multicolumn{2}{|c|}{$F=4.758 ; p=0.010$} & \multicolumn{2}{|c|}{$F=3.771 ; p=0.025$} & \multicolumn{2}{|c|}{$F=4.539 ; p=0.012$} & \multicolumn{2}{|c|}{$F=2.059 ; p=0.131$} \\
\hline $\begin{array}{l}\text { Father's } \\
\text { education }\end{array}$ & \multicolumn{2}{|c|}{$F=1.715 ; p=0.166$} & \multicolumn{2}{|c|}{$F=1.206 ; p=0.310$} & \multicolumn{2}{|c|}{$F=1.511 ; p=0.214$} & \multicolumn{2}{|c|}{$F=1.066 ; p=0.365$} \\
\hline Hearing & \multicolumn{2}{|c|}{$F=6.589 ; p=0.011$} & \multicolumn{2}{|c|}{$F=12.937 ; p=0.000$} & \multicolumn{2}{|c|}{$F=5.737 ; p=0.018$} & \multicolumn{2}{|c|}{$F=0.007 ; p=0.936$} \\
\hline
\end{tabular}

Notes. ${ }^{1}$ Each size is assessed in itself;

${ }^{2}$ Different small letters in the same column are different from the statistical point of view;

${ }^{3}$ Big letters different in the same row are different from the statistical point of view.

Table 10

Hopelessness Scores and Mother's Employment Status

\begin{tabular}{|c|c|c|c|c|c|c|c|c|}
\hline \multirow{2}{*}{$\begin{array}{l}\text { Mother's } \\
\text { employment } \\
\text { status }\end{array}$} & \multicolumn{2}{|c|}{ Hopelessness $^{1}$} & \multicolumn{2}{|c|}{ Feelings for the future } & \multicolumn{2}{|c|}{ Motivation loss } & \multicolumn{2}{|c|}{ Expectations for the future } \\
\hline & $\begin{array}{l}\text { Hearing } \\
\text { impaired }\end{array}$ & Hearing & $\begin{array}{l}\text { Hearing } \\
\text { impaired }\end{array}$ & Hearing & $\begin{array}{l}\text { Hearing } \\
\text { impaired }\end{array}$ & Hearing & $\begin{array}{l}\text { Hearing } \\
\text { impaired }\end{array}$ & Hearing \\
\hline Working & $16.33 \pm 1.60$ & $14.22 \pm 0.83$ & $5.17 \pm 0.48$ & $4.50 \pm 0.32$ & $7.00 \pm 0.95$ & $5.94 \pm 0.59$ & $4.17 \pm 0.47$ & $3.78 \pm 0.29$ \\
\hline Not working & $15.15 \pm 0.45$ & $15.21 \pm 0.49$ & $5.12 \pm 0.214$ & $4.61 \pm 0.15$ & $6.63 \pm 0.26$ & $6.79 \pm 0.30$ & $3.43 \pm 0.13$ & $3.95 \pm 0.15$ \\
\hline Mean & - & - & $5.12 \pm 0.25 \mathrm{~A}^{3}$ & $4.86 \pm 0.16 \mathrm{~B}$ & - & - & - & - \\
\hline $\begin{array}{l}\text { Hearing X } \\
\text { mother's } \\
\text { employment }\end{array}$ & \multicolumn{2}{|c|}{$F=1.219 ; p=0.271$} & \multicolumn{2}{|c|}{$F=0.072 ; p=0.789$} & \multicolumn{2}{|c|}{$F=1.085 ; p=0.299$} & \multicolumn{2}{|c|}{$F=2.491 ; p=0.117$} \\
\hline $\begin{array}{l}\text { Mother's } \\
\text { employment }\end{array}$ & \multicolumn{2}{|c|}{$F=0.010 ; p=0.920$} & \multicolumn{2}{|c|}{$F=0.012 ; p=0.912$} & \multicolumn{2}{|c|}{$F=0.163 ; p=0.687$} & \multicolumn{2}{|c|}{$F=0.956 ; p=0.330$} \\
\hline Hearing & \multicolumn{2}{|c|}{$F=1.082 ; p=0.300$} & \multicolumn{2}{|c|}{$F=3.872 ; p=0.050$} & \multicolumn{2}{|c|}{$F=0.581 ; p=0.447$} & \multicolumn{2}{|c|}{$F=0.055 ; p=0.815$} \\
\hline
\end{tabular}

Notes. ${ }^{1}$ Each size is assessed in itself;

${ }^{2}$ Different small letters in the same column are different from the statistical point of view;

${ }^{3}$ Big letters different in the same row are different from the statistical point of view.

Considering the data given in Table 11, it has been seen that employment status of father has an impact on children's hopelessness levels $(F=6.709 ; p=0.010)$. Hopelessness levels of children with hearing impairment, whose fathers do not work, are found to be higher than hopelessness levels of children without hearing problems. In the subscale of feelings about the future, in the group of children with hearing impairment, hopelessness levels of children whose fathers do not work are found to be higher; whereas in the group of children without hearing impairment, hopelessness levels of children whose fathers have a job are found to be higher than hopelessness levels of children whose fathers do not work, respectively. In the subscale of loss of motivation, results are similar. In the subscale of expectations about the future, hopelessness levels of children 
without hearing impairment, whose fathers have a job, are found to be higher than hopelessness levels of children with hearing impairment, whose fathers have a job.

Table 11

Hopelessness Scores and Father's Employment Status

\begin{tabular}{|c|c|c|c|c|c|c|c|c|}
\hline \multirow{2}{*}{$\begin{array}{l}\text { Father's } \\
\text { employment } \\
\text { status }\end{array}$} & \multicolumn{2}{|c|}{ Hopelessness } & \multicolumn{2}{|c|}{ Feelings for the future } & \multicolumn{2}{|c|}{ Motivation loss } & \multicolumn{2}{|c|}{ Expectations for the future } \\
\hline & $\begin{array}{l}\text { Hearing } \\
\text { impaired }\end{array}$ & Hearing & $\begin{array}{l}\text { Hearing } \\
\text { impaired }\end{array}$ & Hearing & $\begin{array}{l}\text { Hearing } \\
\text { impaired }\end{array}$ & Hearing & $\begin{array}{l}\text { Hearing } \\
\text { impaired }\end{array}$ & Hearing \\
\hline Working & $14.90 \pm 0.49$ & $15.32 \pm 0.46 b^{2}$ & $5.09 \pm 0.14$ & $4.73 \pm 0.13 \mathrm{a}$ & $6.37 \pm 0.29$ & $6.69 \pm 0.27 \mathrm{a}$ & $3.45 \pm 0.14 \mathrm{~B}$ & $4.03 \pm 0.13 \mathrm{aA}$ \\
\hline Not working & $16.31 \pm 0.89 \mathrm{~A}^{3}$ & $12.33 \pm 1.29 \mathrm{aB}$ & $5.21 \pm 0.26 \mathrm{~A}$ & $3.44 \pm 0.38 \mathrm{~b}$ & $7.58 \pm 0.58 \mathrm{~A}$ & $5.88 \pm 0.77 \mathrm{bB}$ & $3.58 \pm 0.26$ & $3.00 \pm 0.38$ \\
\hline $\begin{array}{l}\text { Hearing X } \\
\text { father's } \\
\text { employment }\end{array}$ & \multicolumn{2}{|c|}{$F=6.709 ; p=0.010$} & \multicolumn{2}{|c|}{$F=7.620 ; p=0.006$} & \multicolumn{2}{|c|}{$F=3.894 ; p=0.050$} & \multicolumn{2}{|c|}{$F=5.300 ; p=0.023$} \\
\hline $\begin{array}{l}\text { Father's } \\
\text { employment }\end{array}$ & \multicolumn{2}{|c|}{$F=0.862 ; p=0.355$} & \multicolumn{2}{|c|}{$F=5.347 ; p=0.022$} & \multicolumn{2}{|c|}{$F=0.160 ; p=0.690$} & \multicolumn{2}{|c|}{$F=3.221 ; p=0.075$} \\
\hline Hearing & \multicolumn{2}{|c|}{$F=4.390 ; p=0.038$} & \multicolumn{2}{|c|}{$F=17.603 ; p=0.000$} & \multicolumn{2}{|c|}{$F=1.813 ; p=0.180$} & \multicolumn{2}{|c|}{$F=0.005 ; p=0.996$} \\
\hline
\end{tabular}

Notes. ${ }^{1}$ Each size is assessed in itself;

${ }^{2}$ Different small letters in the same column are different from the statistical point of view;

${ }^{3}$ Big letters different in the same row are different from the statistical point of view.

\section{Discussion and Conclusion}

The hearing loss affects the relationship of an individual and his/her environments in almost every aspect. Unfortunately, these individuals are forced to grow up and live in a relative isolation in the society. Disabilities, such as deafness, adverse environmental conditions, and public order interfere with many desires and needs. These barriers may lead to a variety of intimidations, griefs, and losses and internal life comes to a tense situation (Tunçbilek \& Hatipoğlu, 1988). In consideration of these information, in this study, which was conducted to determine hopelessness levels and factors affecting hopelessness levels of children with and without hearing impairment, age is found to be effective on hopelessness (see Table 2). However, hopelessness levels of children were differed regardless of age when they are 15 years old. Hopelessness levels of 15 years old children with hearing impairment were found to be higher than hopelessness levels of 15 years old children without hearing impairment. These children are in their adolescence period and this period is generally considered to be the most tense and difficult period of their lives. Since children have to deal with very significant changes during this period, they are under intense stress. In addition to these difficulties, having hearing impairment makes this period more difficult and problematic to overcome. As a matter of fact, according to many researchers, individuals with hearing impairment feel left out from the world, isolated with low self-esteem, and hopeless and they are more prone to depression and suicide (Turner et al., 2007; Sahli, Arslan, \& Belgin, 2009; Sheppard \& Badger, 2010; Rostami et al., 2014). The study of Coşkun (2007) supports these findings. However, Küçük and Arıkan (2005) stated that hopelessness levels of children with hearing impairment, who are in the age range of 13-15, are higher than hopelessness levels of children without hearing impairment, but this difference is statistically insignificant. Bayramova and Karadakovan (2004) and Deveci, Ulutaşdemir, and Aç1k (2011) have found no significant differences between age and hopelessness levels.

In the study, it has been determined that gender differences have no impact on hopelessness levels of children (see Table 3). In the subscale of feelings about the future, it has been seen that hearing impairment creates a difference regardless of sex. In this subscale, although it is not statistically significant, hopelessness levels of boys are found to be higher than hopelessness levels of girls. In the subscale of expectations about the 
future, hearing impairment creates a difference regardless of sex. Considering the previous studies conducted, although there are some studies consistent with the findings of this study (Bayramova \& Karadakovan, 2004; Coşkun, 2007; Koç \& Akmeşe Piştav, 2011), there are also some studies suggesting that hopelessness levels of boys are higher that hopelessness levels of girls (Bolland, 2003; Durak Batıün, 2005; Kü̧̈ük \& Arıkan, 2005; Ceylan \& Şahin, 2008; Şahin, 2009; Deveci et al., 2011; Lester, 2015). In addition, in some studies, it can be seen that hopelessness levels of girls are higher that hopelessness levels of boys (Tanhan \& Kardaş, 2014; Yerlikaya, 2014; Baran, Baran, \& Maskan, 2015).

Stereotypes, differences, and prejudices of children other than their biological differences and their roles are defined by society. In the socialization process, differences between emotion, attitude, behavior, and roles of boys and girls appropriate to their genders are social gender differences (Dökmen, 2005). It is thought that hearing impairment plays a more effective role in hopelessness behaviors of children compared to the role of gender. In the subscale of expectations about the future, although it is not statistically significant, since hopelessness levels of boys are higher than hopelessness levels of girls, perspectives of societies regarding boys and girls and cultural education differences can be considered as determinants of hopelessness, because higher expectations of men in Turkey may have affected their level of hopelessness. In other words, hopelessness can be a mechanism that may affect attitudes towards hearing impairment (Wagner, Smith, Ferguson, Horton, \& Wilson, 2009).

Another finding of the study is determining whether receiving pre-school education has any impact on hopelessness levels of children (see Table 4). In the subscale of feelings about the future, hearing impairment has created a difference regardless of receiving pre-school education. It can be seen that hopelessness levels of children with hearing impairment are higher than hopelessness levels of their peers. In fact, having pre-school education is very important for children with hearing impairment. In this way, children can overcome many communication and consequently social problems, such as speaking properly or understanding the conversation. Children included in the study have mild or moderate hearing impairment and more than half of them (52\%) have received pre-school education. Children with hearing impairment going to the same school with children without hearing impairment compare themselves with these children and experience all challenges by realizing their disabilities. From this point of view, it is inevitable that children with hearing impairment have to face impacts of these emotional and social trauma in their older ages. Although hopeless people have control over their own lives, they think that the problem has no solution and they cannot reach their goals. The lack of environmental support elements will also reinforce this feeling. These reasons seem to be effective on results obtained from the subscale of expectations about the future.

Although having a family member with hearing impairment or another disability increases hopelessness levels of children with hearing impairment, it does not create any statistically significant difference (see Table 5). Küçük and Arıkan (2005) tried to determine hopelessness levels of children with hearing impairment and suggested that hopelessness levels of children stating that they have a family member with hearing impairment are close to each other regardless of whether they are hearing impaired or not. The existence of a disabled family member/members in the family brings special challenges and affects all family members either directly or indirectly (Spink, 1976; Laurie, Fortier, \& Richard, 1984; Lyon, Albertus, Birkinbine, \& Naibi, 1996). Hearing impairment takes place in human lives with communication problems and other challenges caused by these problems. If a common language is developed in families formed by hearing impaired individuals; then, relationships, attitudes and behaviors, and dynamics in and out of family are achieved in a healthy way. 
It is known that problems occurring in families without hearing impaired individuals are caused by the lack of communication and failures in communication. In families formed by individuals with hearing impairment, many factors, such as number of individuals with disabilities, type and degree of these disabilities, their self-understandings and approaches towards problems caused by these disabilities, educational levels, socio-cultural factors, and environmental support factors have effects on children when they evaluate themselves. However, even if these children face no communication problems with family members, they experience challenges and problems caused by their impairment when they are outside and they isolate themselves from the world if there are no environmental support elements when they discover their differences and persistence of this situation. Although it has been assumed that this situation has impacts on hopelessness levels of children, in this study, the number of families consist of persons with disabilities only is eight. Therefore, this study cannot have a reliable comparison of these children in terms of their hopelessness levels.

The data regarding age of mother are presented in Table 6 while the data regarding the age of father are given in Table 7, respectively. Considering these data, both ages of mother and father have no impact on hopelessness levels of children. However, it is noteworthy that hopelessness levels of children with hearing impairment, who have elder parents, are quite high. According to some studies conducted, parents who have children with hearing impairment become more protective towards their children (Temel, Ersoy, \& Şahin, 1998; Brubaker \& Szakowski, 2000; Dönmez, Bayhan, \& Artan, 2000). Because these children experience danger, being ridiculed, and condemned outside the family, therefore, parents try to protect their children from all this negativities. This makes children more dependent to the family. Changes in physical, mental, and emotional capacities of parents with their increasing age are another sources of concern. The possibility of getting sick increases as parents get older and even death can come to the mind. These reasons may have affected the hopelessness levels of children. In the subscale of feelings about the future, hopelessness levels of children with hearing impairment are higher than hopelessness levels of their peers without hearing problems regardless of age of their parents. Hope and hopelessness are opposite concepts. Hope can be defined as having expectations to reach a particular goal in the future, whereas hopelessness can be defined as negative expectations. Individuals make plans for the future as long as they have hope (Dilbaz \& Seber, 1993; Abbey, 2006). Individuals in their adolescence period try to combine their expectations towards their past, present time, and futures in order to create their identities. Hearing impairment may have created negativities in terms of their future expectations. Akandere, Acar, and Baştuğ (2009) determined that in the subscale of feelings about the future, hopelessness scores of elderly fathers who have children with disabilities are higher than younger fathers.

According to the results of the study, mother's educational level has no impact on hopelessness levels of children (see Table 9). In some studies conducted on the same subject, there are similar results (Küçük \& Arıkan, 2005; Şahin, 2009). In fact, educational level of mother has an impact on determination of strategies developed by children when they encounter a problem and on their behaviors. Furthermore, it has been determined that problem-solving skills of highly educated parents are better than other parents and these parents can better identify adaptation strategies (Quine \& Pahl, 1991). Haveman, Gottlieb, and Heller (1997) reported that mothers with lower educational level spend less time for themselves and experience more intense care responsibilities for their children. Positive approaches of mothers and use of social support networks are protective against depression and hopelessness (Hammen, Burge, \& Adrian, 1991; Abela, 2001). In addition, low educational levels of mothers $(75.31 \%$ have primary education and $24.69 \%$ are illiterate) of children included in the study are thought to be effective on the results of this study. 
As it can be seen in Table 9, it has been seen that educational level of father has an impact on children's hopelessness levels. Hopelessness levels of children with hearing impairment, whose fathers are illiterate or holding a high school degree, are found to be higher compared to other children. In addition, while hopelessness levels of children with hearing impairment, whose fathers are illiterate or holding a high school degree, are higher; hopelessness levels of children without hearing impairment, whose fathers are graduated from universities, are found to be higher, respectively. Relationship between father and child is extremely important for a child's mental and physical health regardless of any disability. According to the studies conducted, children established healthy communication with their fathers are psychologically well adjusted, they have higher self-esteem and exhibit less anti-social behaviors and bond between children with hearing impairment and their parents is no different than the bond between children without hearing impairment and their parents (Fluori \& Buchanan, 2003; Ozşenol, Işıkhan, Gunay, Aydın, Akın, \& Gökçay, 2003). The role of father in terms of personalization of the child is very important and he has a facilitating role for children to accept the impairment condition. In this process, educating father is important. As in mothers, educational level of fathers has positive impacts on their approaches, attitudes, and adaptation to the situation. Awan, Bibi, and Chaudhry (2015) determined the existence of a relationship between attitudes of families, who have children with mental retardation, and hopelessness. However, Sahin (2009) found that educational level of father has no impact on hopelessness levels of healthy children. In addition, Hoffman, Quittner, and Cejas (2015) determined that educational levels of families who have children with hearing impairment are quite low. In this study, $11.1 \%$ of the fathers are illiterate and $82.725 \%$ of them are primary school graduates, respectively. These results are consistent with findings of Hoffman et al. (2015).

As it can be seen in Table 10, employment status of mother has no impact on hopelessness levels of children. In addition, in the group of children with hearing impairment, although it is not statistically significant, hopelessness levels of children, whose mothers have a job, are found to be higher; whereas in the group of children without hearing impairment, hopelessness levels of children, whose mothers do not have a job, are found to be higher, respectively. In the study of Babaroglu and Baran (2006) conducted on children with leukemia, it has been concluded that employment status of mother has no significant impact on hopelessness levels of children. Mothers generally take more responsibility in matters concerning children. In this period, the mother is an indispensable element for children with hearing impairment and these children consider their mothers as a bridge that allows them to establish relationship with life and the outside world. Therefore, working mother means lack of this bridge for children with hearing impairment and being deprived of the most important and reliable support. Although mothers who have a child with hearing impairment may choose not to work, this may not work for other mothers with no hearing impaired children, because mothers who have a job financially support the family. In addition, working mothers experience less stress and use more social support mechanisms (Çavuşoğlu, 1992; Gallagher, Beckman, \& Cross, 1993; Hersh \& Weiner, 1993). It has been thought that this affects hopelessness levels of children without hearing problems. In the subscale of feelings about the future, hearing impairment creates a difference regardless of employment status of mother. In this subscale, hopelessness levels of children with hearing impairment are found to be higher than hopelessness levels of children without hearing impairment. Hearing impairment has an impact on self-esteem. According to the studies conducted, children with hearing impairment have low self-esteem (Leigh \& Stinson, 1991; Ekim \& Ocakc1, 2012). Self-esteem is an important protector for the mental health of the individuals and it is correlated with expectations and coping mechanisms of an individual (Masten, 2001; Baumeister, Campbell, Krueger, \& 
Vohs, 2003; Flory, Lynam, Milich, Leukefeld, \& Clayton, 2004; Donnellan, Trzesniewski, Robins, Moffitt, \& Caspi, 2005). These structures may have impacts on results obtained in the subscale of feelings about the future.

As it can be seen in Table 11, employment status of father has an impact on children's hopelessness levels. Hopelessness levels of children with hearing impairment, whose fathers do not work, are found to be higher than hopelessness levels of children without hearing problems. In the subscales of feelings about the future and loss of motivation, results are similar. In the subscale of expectations about the future, hopelessness levels of children without hearing impairment, whose fathers have a job, are found to be higher than hopelessness levels of children with hearing impairment, whose fathers have a job. Employment status of father is also associated with socio-economic level of the family. Although this is not the only determinant of hopelessness, it may affect some factors either directly or indirectly, because children with disabilities need more care and support compared to their peers. Diagnosis of the impairment, treatment, and making appropriate instrumentation and receiving almost all necessary trainings and support processes are associated with economic conditions of the family. In this case, unemployed fathers may cause the lack of these supports and some negativities. In some studies, hopelessness levels of children coming from families with low income levels are found to be high (Aydoğan-Akınc1, 1999; Özmen et al., 2008; Bayramova \& Karadakovan, 2014; Baran et al., 2015). In addition, Küçük and Arıkan (2005) have determined that hopelessness levels of children whose fathers are farmer are lower than hopelessness levels of children whose fathers are teacher. Thus, it has been thought that all these factors may have impacts on hopelessness levels of children with hearing impairment. In children without hearing impairment, since fathers do not spend sufficient time with their children and the primary person responsible to take care of the children is children's mother, this may have affected the results.

\section{References}

Abbey, J. G. (2006). Hopelessness at the end of life: The utility of the hopelessness scale with terminally ill cancer patients. British Journal of Health Psychology, 11, 173-183. doi:10.1348/135910705X36749

Abela, R. Z. J. (2001). The hopelessness theory of depression: A test of the diathesis-stress and casual mediation components in third and seventh grade children. Journal of Abnormal Child Psychology, 29(3), 241-254.

Akandere, M., Acar, M., \& Baştuğ, G. (2009). Investigating the hopelessness and life satisfaction levels of the parents with mental disabled child. The Journal Institute of Social Sciences, 22, 23-32.

Awan, E. A., Bibi, F., \& Chaudhry, A. G. (2015). Relationship of depression, hopelessness and associated attitude among parents of mental retarded children. Pakistan Association of Anthropology, 27(1), 723-726.

Aydoğan-Akınc1, A. (1999). Determination the level of hopelessness of parents of handicapped children (Unpublished doctoral dissertation, Hacettepe University).

Babaroglu, A., \& Baran, G. (2006). A study on hopelessness levels of children with leukemia and their mothers. Journal of Qafqaz University, 18, 159-165.

Baran, M., Baran, M., \& Maskan, A. (2015). A study on adolescent students levels of hopelessness, loneliness and self-esteem: A sample from Turkey. Mediterrenean Journal of Social Sciences, 6(2), 341-353. doi:10.5901/mjss.2015.vbn2s1p341

Baumeister, R. F., Campbell, J. D., Krueger, J. I., \& Vohs, K. E. (2003). Does high self-esteem cause better performance, interpersonal success, happiness, or healthier life styles? Psychological Science in the Public Interest, 4, 1-44.

Bayramova, N., \& Karadakovan, A. (2004). Determine hopelessness of patients who has a chronic. Atatürk University Journal of Nursing, 7(2), 39-47.

Beck, A. T., Kovacs, M., \& Weissman, A. (1975). Hopelessness and suicidal behavior: An overview. Journal of American Medical Association, 234(11), 1146-1149. doi:10.1001/jama.1975.03260240050026

Beck, A. T., Lesker, D., \& Trexler, L. (1974). The hopelessness scale. Journal of Consulting and Clinical Psychology, 42(6), 861-874.

Bolland, J. M. (2003). Hopelessness and risk behavior among adolescents living in high-poverty inner-city neighborhoods. Journal of Adolescence, 26(2), 145-158. 
Bolland, J. M., Mccallum, D. M., Lian, B., Bailey, C. J., \& Rowan, P. (2001). Hopelessness and violence among inner-city youths. Maternal and Child Health Journal, 5(4), 237-244.

Bonner, R. L., \& Rich, A. R. (1991). Predicting vulnerable to hopelessness, a longitudinal analysis. The Journal of Nervous and Mental Disease, 179(1), 29-32.

Brubaker, G. R., \& Szakowski, A. (2000). Parenting practices and behavior problems among deaf children. Child and Family Behavior Therapy, 22(4), 13-28. doi:10.1300/J019v22n04-02

Çavuşoğlu, H. (1992). Kronik ölümcül hastalık kavramları ile hematolojik ve onkolojik sorunu olan çocuk ve hemşirelik bakımı (Choronic and fatal illnesses notions with hematologic and oncologic problems with children and nursing care) (1st ed.). Ankara: Hürbilek Matbaacilık.

Ceylan, R., \& Şahin, C. (2008). An analysis of despair levels of students studying at primary school teaching department. Paper presented at The 7th National Primary School Teaching Semposium, Çanakkale.

Coşkun, Y. (2007). Examination of the relationship between hopelessness and family relations on high school students according to some variables. Marmara University Journal of Educational Sciences, 25, 11-26.

Demir, T., Bolat, N., Yavuz, M., Karaçetin, G., Doğangün, B., \& Kayaalp, L. (2014). Attachment characteristics and behavioral problems in children and adolescents with congenital blindness. Archives of Neuropsychiatry, 51, 116-121. doi:10.4274/npa.y6702

Derman-Taner, M. (2013). Determining the relationship between aggressiveness and hopelessness levels of 10-11 years of children. International Journal of Social Science, 6(2), 879-889.

Derman-Taner, M. (2013). Determining the relationship between aggressiveness and hopelessness levels of 10-11 years of children. International Journal of Social Science, 6(2), 879-889.

Deveci, S. E., Ulutaşdemir, N., \& Açık, Y. (2011). The levels of hopelessness in the students of an occupational education center and affecting factors. Dicle Medical Journal, 38(3), 312-317. doi:10.5798/diclemedj.0921.2011.03.0039

Dilbaz, N., \& Seber, G. (1993). Umutsuzluk kavramı: Depresyon ve intiharda önemi (The hopelessness notion: The importance of depression and suicide). Kriz Dergisi, 1(3), 134-138.

Dökmen, Ü. (2005). Sosyometri ve psikodrama (Sociometry and psychodrama). Istanbul: Sistem Yayıncılık.

Dönmez, N., Bayhan, P., \& Artan, I. (2000). Engelli çocuğa sahip ailelerin beklentileri ve endişe duydukları konuların incelenmesi (Examination of the issues that expectations of the families with disabled children and concerned). Sosyal Hizmetler Dergisi, 11, 16-24.

Donnellan, M. B., Trzesniewski, H. K., Robins, W. R., Moffitt, E. T., \& Caspi, A. (2005). Low self-esteem is related to aggression, antisocial behavior and delinquency. Psychological Science, 16(4), 328-335. doi:10.1111/j.0956-7976.2005.01535.x

Durak Batıgun, A. (2005). Suicide probability: An assessment terms of reasons for living, hopelessness and loneliness. Turkish Journal of Psychiatry, 16(1), 29-39.

Durak, A. (1994). Beck Umutsuzluk Ölçeği (BUÖ) geçerlik ve güvenirlik çalışması (Study of Beck Hopelessness Scale validity and reliability). Türk Psikoloji Dergisi, 9(31), 1-11.

Dyer, J. A. T., \& Kreitman, N. (1984). Hopelessness, depression and suicidal intent in parasuicide. British Journal of Psychiatry, 144(2), 127-133. doi:10.1192/bjp.144.2.127

Eisenbraun, K. D. (2007). Violence in schools: Prevalence, prediction and preventation. Aggression and Violence Behaviour, 12(4), 459-469.

Ekim, A., \& Ocakçı, A. F. (2012). 8-12 yaş arası işitme engelli çocuklarda yaşam kalitesi (Quality of life in hearing impairment children aged 8-12 years). Ankara Sağlık Hizmetleri Dergisi, 11(1), 17-23.

Fellinger, J., Holzinger, D., \& Pollard, R. (2012). Mental health of deaf people. The Lancet, 379(9820), $1037-1044$. doi:10.1016/S0140-6736(11)61143-4

Flory, K., Lynam, D., Milich, R., Leukefeld, C., \& Clayton, R. (2004). Early adolescent through young adult alcohol and marijuana use trajectories: Early predictors, young adult outcomes, and predictive utility. Development and Psychopathology, $16,193-213$.

Fluori, F., \& Buchanan, A. (2003). The role of father involvement in children's later mental health. Journal of Adolescence, 26, 63-78.

Gallagher, J. J., Beckman, P., \& Cross, A. H. (1983). Families handicapped children: Sources of stress and its amelioration. Exceptional Children, 50(1), 10-19.

Gençöz, F., Vatan, S., \& Lester, D. (2006). Reliability and validity study of hopelessness, helplessness, haplessness scale in a Turkish sample. Journal of Crisis, 14(1), 21-29. doi:10.1501/Kriz_0000000244 
Hammen, C. L., Burge, D., \& Adrian, C. (1991). Timing of mother and child depression in a longitudinal study of child at risk. Journal of Consulting and Clinical Psychology, 59, 341-345.

Haveman, M., Gottlieb, R. R., \& Heller, T. (1997). Differences in service needs, time demand and caregiving burden among parents of persons with mental retardation across the life cycle. Family Relations, 46, 417-425.

Hersh, S. P., \& Wiener, L. S. (1993). Psychological support for to the family of the children with cancer. In P. A. Pizzo, \& D. G. Poaplock (Eds.), Principles and practice of pediatric oncology (pp. 897-913). Philadelphia: Lippincott Company.

Hoffman, M. F., Quittner, A. L., \& Cejas, I. (2015). Comparisons of social competence in young children with and without hearing loss: A dynamic systems framework. Journal of Deaf Studies and Deaf Education, 20(2), 115-124. doi:10,1093/deafed/enu040

Koç, E. R., \& Akmeşe Piştav, P. (2011). Comparison of the levels of anxiety, depression and hopelessness of patient epilepsy and healthy individuals. Turkish Journal of Neurology, 17, 189-194.

Küçük, Y., \& Arıkan, D. (2005). The determination of the hopelessness levels of children with hearing impaired. International Journal of Human Sciences, 2(2), 1-13.

Laurie, M., Fortier, L. W., \& Richard L. W. (1984). Family crisis following the diagnosis of a handicapped child. Family Relations, 33(1), 13-24.

Leigh, I. W., \& Stinson, M. S. (1991). Social environments, self perceptions, and identity of hearing impaired adolescents. Volta Review, 93(5), 7-22.

Lester, D. (2015). Hopelessness in adolescents. Journal of Affective Disorders, 173, 221-225. doi:10.1016/j.jad.2014.10.048

Lyon, M. A., Albertus, C., Birkinbine, J., \& Naibi, J. (1996). A validity study of the social skills rating system teacher version with disabled and nondisabled preschool children. Perceptual and Motor Skills, 83(1), 307-316.

Masten, A. S. (2001). Ordinary magic: Resilience process in development. American Psychologist, 56(3), 227-238.

Minkoff, K., Bergman, E., Beck, A. T., \& Beck, R. (1973). Hopelessness, depression and attempted suicide. The American Journal of Psychiatry, 13(4), 455-459.

Özmen, D., Erbay Dündar, P., Çetinkaya, A. Ç., Taşkın, O., \& Özmen, E. (2008). Hopelessness and factors affecting hopelessness in high school students. Anatolian Journal of Psychiatry, 9, 8-15.

Ozşenol, F., Işıkhan, V., Gunay, B., Aydın, H. I., Akın, R., \& Gökçay, E. (2003). The evaluation of family functions at families with handicapped children. Gülhane Medical Journal, 45(2), 156-164.

Quine, L., \& Pahl, J. (1991). Stress and coping in mothers caring for a child with severe learning difficulties: a test of Lazarys Transcation Model of coping. Journal of Community and Applied Social Psychology, 1, 57-70.

Rostami, M., Bahmani, B., \& Bakhtyari, V. (2014). Depression and deaf adolescent: A review. Iranian Rehabilitation Journal, 12(19), 43-52.

Şahin, C. (2009). Hopelessness levels of students studying at faculty of education. Selçuk University, Ahmet Keleşoğlu Education Faculty Journal, 27, 271-286.

Sahli, S., Arslan, U., \& Belgin, E. (2009). Depressive emotioning in adolescents with cochlear implant and normal hearing. International Journal of Pediatric Otorhinolaryngology, 73(12), 1774-1779. doi:10.1016/j.jiporl.2009.09.027

Seber, G. (1991). A study of the validity and reliability of Beck's Hopelessness Scale (Unpublished doctoral dissertation, Anadolu University).

Sheppard, K., \& Badger, T. (2010). The lived experience of depression among culturally deaf adults. Journal of Psychiatric Mental Health Nursing, 17(9), 783-789. doi:10.1111/j.1365-2850.2010.01606.x

Spink, D. (1976). Crisis intervention for parents of the deaf child. Health and Social Work, 1, 140-160.

Tanhan, F., \& Kardaş, F. (2014). Investigating hopelessness and trauma levels of high school students exposed to the Van earthquake. Sakarya University Journal of Education, 4(1), 102-115.

Tatar, Y., Çekin, M. D., \& Uzun, S. (1997). Yatılı okul eğitiminin işitme özürlülerin ruh durumlarına etkileri. Düşünen adam (The effects on mood hearing impaired of the boarding school's education). Psikiyatri ve Nörolojik Bilimler Dergisi, 10(3), 52-56.

Temel, F., Ersoy, O., \& Şahin, F. (1998). 15-18 yaş arasındaki işitme engelli gençlerin karşılaştıkları problemlerin incelenmesi (Examination of the encounter problems young people aged between 15-18 with hearing impairments). Proceedings of The National Congress of Educational Sciences, Konya.

Theunissen, S. C. P. M., Rieffe, C., Kouwenberg, M., De Raeve, L. J. I., Soede, W., Briaire, J., \& Frijns, J. H. M. (2014). Behavioral problems in school aged hearing-impaired children: The influence of sociodemographic, linguistic, and medical factors. European Child Adolescence Psychiatry, 23, 187-196. doi:10.1007/s00787-013-0444-4

Tunçbilek, E., \& Hatipoğlu, S. (1988). Economic, social and psychological changes taking place within the family and children who have chronic diseases and have been treated in the hospital. Turkish Journal of Nursing, 38(1), 37-42. 
Turner, O., Windfuhr, K., \& Kapur, N. (2007). Suicide in deaf populations: A literature review. Annals of General Psychiatry, 6(26), 1-9. doi:10.1186/1744-859x-6-26

Vasta, R. A. (2015). Hopelessness: Developmental, cultural, and clinical realms. In S. Akhtar, \& M. K. O’Neil (Eds.), Adolescent hope and hopelessness (pp. 43-56). London, U.K.: Karnac Books Ltd..

Wagner, J. L., Smith, G., Ferguson, P., Horton, S., \& Wilson, E. (2009). A hopelessness model of depressive symptoms in youth with epilepsy. Journal of Pediatric Psychology, 34(1), 89-96. doi:10.1093/jpepsy/jsn052

Weissman, M. M. (1974). The epidemiology of suicide attempts. Archives of General Psychiatry, 30(6), 737-746.

World Health Organization. (2011). World report on disability. Retrieved from http://www.who.int/disabilities/world_report/2011 en./23.04.2015

Yerlikaya, I. (2014). Determination of hopelessness level of state and private middle school students and investigation of its relation with certain variables. International Periodical for the Literature and History of Turkish or Turkic, 9(8), 865-877. 